\title{
Water intake and excretion, urinary solute excretion and some stress indicators in mink (Mustela vison): effect of ambient temperature and quantitative water supply to lactating females
}

\author{
Anne-Helene Tauson \\ Department of Animal Nutrition and Management, Funbo Lövsta Research Station, Swedish University of Agricultural \\ Sciences, S-755 97 Uppsala, Sweden
}

(Received 6 February 1998 - Revised 20 June 1998 - Accepted 24 June 1998)

\begin{abstract}
Lactation is a physiologically demanding period in mink production, during which kit and dam losses may occur. Ambient temperature and quantitative water supply are thought to affect animal performance and well-being, but conclusive data in the literature are sparse. Therefore, effects of ambient temperature $\left(T_{a}\right.$; low, about $5^{\circ}$; medium, about $15^{\circ}$; high, average $\left.20-25^{\circ}\right)$ and water supply (ad libitum $(\mathrm{N})$, or $10 \%$ extra supplementation in the food $(\mathrm{E}))$ were investigated regarding effects on quantitative water intake and excretion, urine osmolality and solute excretion, and urinary cortisol and catecholamines as stress indicators in an experiment with twelve lactating mink with litters of three to seven kits in three consecutive periods, lasting 3, 3 and $2 \mathrm{~d}$ respectively. Kit ages ranged from 15 to $20 \mathrm{~d}$ at the end of the experiment. Water requirement for milk production (factorial calculations) and water available for evaporation (balance component) were estimated. Period, and hence mainly $\mathrm{T}_{\mathrm{a}}$, had a significant influence on intake of metabolizable energy, quantitative water intake and excretion, but there was less effect of water supply. The total water intake and excretion were very high in relation to the weight of the animals as an effect of lactation. Water intake and excretion, and urinary $\mathrm{Na}$ excretion, seemed to be less accurately regulated compared with corresponding functions in non-lactating animals. Rectal temperature increased with increasing $T_{a}$, possibly as a means of decreasing evaporative water loss. Water output in milk was estimated to increase from $118 \mathrm{~g} / \mathrm{d}$ at low $\mathrm{T}_{\mathrm{a}}$ to $134 \mathrm{~g} / \mathrm{d}$ at high $\mathrm{T}_{\mathrm{a}}$. The amounts of water available for evaporation were estimated to be 42,58 and $69 \mathrm{~g} / \mathrm{kg}^{0.75}$ at low, medium and high $\mathrm{T}_{\mathrm{a}}$. Cortisol data did not indicate that the animals experienced negative stress. It was concluded that prolonged periods of high $\mathrm{T}_{\mathrm{a}}$ may be hazardous for lactating mink because of decreased intake of metabolizable energy resulting in energy deficit and excessive mobilization of body reserves simultaneously as the requirement for intake of water increases considerably.
\end{abstract}

Water balance: Urinary electrolytes: Stress: Mink

Lactation puts heavy demands on the mechanisms regulating water balance, and water turnover is usually increased to a considerable extent. Furthermore, lactating animals have a restricted ability to regulate fluid losses via milk. The strain of the lactation period is certainly evident for the female mink. Average litter sizes have increased profoundly in the Scandinavian countries during the last two decades, and amount currently to about six kits. The kits are totally dependent on the energy and nutrients provided by their mother's milk until the age of almost 4 weeks, when they start to take some solid food in addition to sucking.
Therefore, a sufficient supply of energy, nutrients and water to the lactating dam is necessary to support performance, health and survival of dam and offspring, but even in a situation of adequate nutrition, survival and health may be endangered by internal and external factors.

The kits are born in a very vulnerable state, with a fat content of slightly about $10 \mathrm{~g} / \mathrm{kg}$ in the body (Tauson, 1994a) and since they are blind, nearly hairless, with limited locomotor ability, as well as being devoid of an efficient thermoregulatory capacity, lactation has to be established soon after parturition. Thus, an ample milk supply is

\footnotetext{
Abbreviations: E, group of mink receiving extra dietary water; EGTA, ethylene glycol-bis-(beta-aminoethylether)-N,N, $\mathrm{N}^{\prime}, \mathrm{N}^{\prime}$-tetraacetic acid; ME, metabolizable energy; $\mathrm{ME}_{\mathrm{g}}, \mathrm{ME}$ requirement for growth; $\mathrm{ME}_{\mathrm{m}}$, $\mathrm{ME}$ requirement for maintenance; $\mathrm{N}$, group of mink receiving ad libitum water supply; $\mathrm{T}_{\mathrm{a}}$, ambient temperature.

Corresponding author: Dr Anne-Helene Tauson, present address: Department of Animal Science and Animal Health, Royal Veterinary and Agricultural University, Bülowsvej 13, DK-1870 Frederiksberg C, Denmark, fax +45 352830 20, email aht@kvl.dk
} 
essential for good survival rate and optimal growth performance during the suckling period. However, the kits have the capacity for rapid growth, with a maximum relative growth rate of $23 \%$ in $24 \mathrm{~h}$ between days 1 and 2, and an average of $9 \%$ in $24 \mathrm{~h}$ over the total $42 \mathrm{~d}$ lactation period. Hence, body weight is increased from about $10 \mathrm{~g}$ at birth to 300-350 g at weaning (Tauson, 1994a).

Quantitative determination of the milk production in mink is, as in most other polytocous animals, difficult to conduct, and therefore reliable information is scarce. A single study with direct measurements made by an isotope dilution technique (Wamberg \& Tauson, 1998) and estimates by factorial calculations (Hansen, 1997; Tauson et al. 1998) indicate that milk production can be considered high for a small-sized animal, females with a live weight of about $1000 \mathrm{~g}$ and with litters of six or seven kits producing about $4000 \mathrm{~g}$ milk during the first 4 weeks of lactation. The energy requirement of the lactating dam, therefore, increases steeply as lactation progresses, and after the third week of lactation females with large litters usually are unable to increase their food intake sufficiently to sustain their metabolizable energy (ME) requirement, and consequently have to mobilize fat reserves from the body (Tauson, 1997; Tauson et al. 1998). Even in healthy females a weight loss in the order of $15-25 \%$ can occur during the lactation period, most of it taking place after the third week of lactation (Tauson, 1988, 1994b; Hansen \& Berg, 1998).

During the late part of lactation, female mink may be affected by nursing sickness, the aetiology of which is still somewhat obscure, but involves energy and water deficit. The prevalence varies, but Clausen et al. (1992) reported a morbidity of $14 \%$ and a mortality of $7 \%$. Affected females are usually emaciated and dehydrated, and during the late stage of illness the animals refuse both food and drinking water. Pathophysiological findings include changes showing a decrease in extracellular fluid volume, electrolyte deprivation and a disturbed acid-base balance (Wamberg et al. 1992).

The apparently simple task of supplying sufficient amounts of energy and water may, however, have considerable limitations. During the lactation period ambient temperature $\left(\mathrm{T}_{\mathrm{a}}\right)$ may vary to a great extent; many locations where mink farming occurs are likely to experience periods of high $\mathrm{T}_{\mathrm{a}}$, and practical experience has shown that the risk for kit and female mortality increases at high $\mathrm{T}_{\mathrm{a}}$. Evaporative water loss from the body of small kits may cause dehydration (Wustenberg \& Wustenberg, 1988), and females with high obligatory water loss are also at risk. $T_{a}$ has been demonstrated to have a great influence on $\mathrm{ME}$ intake and water intake and excretion traits of male mink under laboratory conditions. When $\mathrm{T}_{\mathrm{a}}$ was high, ME intake was low, resulting in a decreased dietary water intake, whereas the requirement of drinking water increased as well as evaporative water loss (A-H Tauson, unpublished results; Wamberg, 1994). The quantitative water supply also had some influence on water intake and excretion traits. Generally, even a limited restriction in the access to drinking water resulted in a decreased water intake, water excretion in urine was decreased concomitantly and, consequently, urinary osmolality increased, but if extra water was added to the food the opposite occurred (A-H Tauson, unpublished results; Neil, 1988). In addition, mink diets are high in protein, and water will be required for excretion of excess $\mathrm{N}$. Therefore, several factors will make the female mink vulnerable to shortage of water or an augmentation of the demands, for instance induced by high $\mathrm{T}_{\mathrm{a}}$.

The supply of drinking water to lactating mink may, therefore, be crucial for both performance and animal welfare reasons. Both $T_{a}$ and quantitative water supply may be considered as very important factors for the water intake and excretion and total water balance, and in lactating females their influence may be expected to be strongly determining for animal performance and health.

The objectives of the present study were first, to study how $\mathrm{T}_{\mathrm{a}}$ influenced water intake and excretion traits, including urinary osmolality and solute excretion, in lactating dams, and how animal performance was affected by changes in $\mathrm{T}_{\mathrm{a}}$. Second, it was the intention to estimate if facilitation of water intake by addition of extra water in the food influenced water intake and excretion traits and animal performance to any extent. Third, it was the aim to assess if variation in $\mathrm{T}_{\mathrm{a}}$ and quantitative water supply imposed stress in the animals as measured by $24 \mathrm{~h}$ urinary excretion rates of cortisol and catecholamines.

\section{Materials and methods}

\section{Animals and general design of the experiment}

The experiment was carried out at Funbo Lövsta Research Station with ten yearling and two 3-year-old female mink of the standard black genotype (Nes et al. 1987) originating from the breeding herd of our experimental farm and kept under conventional housing conditions, i.e. exposed to prevailing fluctuations in outdoor temperature. The females had given birth during the period 3-8 May, and the experimental animals were chosen among females with litter sizes of three to seven kits. The animals were free from plasmacytosis according to a counter immunoelectrophoresis test (Hansen, 1974). They were housed in one end of a two-row closed, but non-insulated, mink house with a concrete floor. The cages had a floor area of $0.9 \times 0.3 \mathrm{~m}$ and a height of $0.4 \mathrm{~m}$. All cages had a nest box especially furnished for lactating animals. The cages were equipped with individual water bottles connected to conventional drinking nipples and jars to collect water spill. The animals were individually fed once daily in cups, placed on trays to permit collection of food waste. The experiment consisted of three periods carried out consecutively, and lasting 3, 3 and $2 \mathrm{~d}$ respectively. During the first period (low $\mathrm{T}_{\mathrm{a}}$ ) the average temperature was about $5^{\circ}$, with a minimum of $0^{\circ}$ and a maximum of $10^{\circ}$. During the following two periods, $T_{a}$ was increased by means of two heaters with fans placed so as to distribute their heat as evenly as possible in the area in which the animals were housed. In the second period (medium $\mathrm{T}_{\mathrm{a}}$ ) average temperature was about $15^{\circ}$, with a minimum and maximum of $7^{\circ}$ and $25^{\circ}$ respectively. The third period (high $\mathrm{T}_{\mathrm{a}}$ ) had an average temperature of between $20^{\circ}$ and $25^{\circ}$, with a minimum of $14^{\circ}$ and a maximum of $30^{\circ}$. Since the house in which the animals were kept was not insulated, the diurnal fluctuations in temperature mainly reflected outdoor differences between 
night and day. In order to keep relative humidity as even as possible, the concrete floor was sprinkled with water several times daily during the periods of medium and high $\mathrm{T}_{\mathrm{a}}$.

The animals were given drinking water ad libitum (normal; N) or were given extra water supplementation (E) in the food (water equalling $10 \%$ of the original weight of the food was added before feeding). The general outline of the experiment, litter sizes and kit ages are given in Table 1. The experimental procedures were approved by the Ethical Committee for Experimentation with Animals, Sweden.

\section{Diet and food supply}

The daily food supply was $400 \mathrm{~g}$, which was calculated to support the energy requirement of the females with the largest litters and the oldest kits throughout the experiment (Hansen et al. 1991). The diet contained (g/kg): cod offal 300 , Baltic herring 100, filleting scrap (heads and backbones) of Baltic herring 100 (both from herring caught during the spring), slaughter house offal 150, poultry wastes 150, a mixture of extruded wheat, oats and barley 50 , and potato mash powder 30 . Vitamins were added according to standards (Juokslahti, 1987). The analysed chemical composition of the diet (g/ $\mathrm{kg}$ ) was: DM 274, ash 26 , crude protein 132 , fat 70 , carbohydrate calculated by difference 46, and gross energy $1600 \mathrm{~kJ} / \mathrm{kg}$. All the food was prepared on one occasion before the start of the experiment and daily portions were weighed and stored deep-frozen until the day before feeding. The food was thawed in a refrigerator overnight. For animals on E water supply, $40 \mathrm{~g}$ water was stirred into each portion before it was presented to the animals.

\section{Data collection}

Females and individual kits were weighed at the start and at the end of each period, at and the end of each period rectal temperatures of the females were recorded. Daily consumption of drinking water was recorded. Quantitative collection of food refusals, food wastes, faeces and urine was carried out daily. Faeces were collected on netting screens placed under the cages, and urine was collected via funnels into plastic bottles. The collection procedures started at 09.00 hours, and feeding took place when the collection procedure was completed, at approximately 12.00 hours. In order to determine the original water content of the faeces, small samples were taken as soon after voiding as possible, and when calculating water output in faeces, faecal DM was corrected to the level of fresh faeces. The food refusals, wastes and faeces were frozen until analysis. From the urine, two daily samples were taken out and deep-frozen. On the last day of each collection period, urine from every second animal ( $n$ 6) was collected for catecholamine analyses (see later) in $4 \mathrm{ml} 6 \mathrm{M}-\mathrm{HCl}(\mathrm{pH} \mathrm{1-2).} \mathrm{A} \mathrm{solution}$ consisting of $90 \mathrm{mg} / \mathrm{ml}$ ethylene-glycol-bis-(beta-amino-

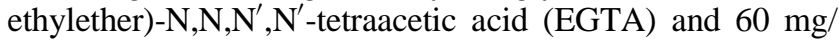
$\mathrm{ml}$ glutathione was used as a preservative, and $20 \mu \mathrm{l}$ EGTAglutathione solution was used per $5 \mathrm{ml}$ urine.

\section{Analyses}

Contents of DM were determined in all samples. Before further analyses, diets, faeces and urine were freeze-dried. Diets and faeces were analysed for ash, crude protein $(\mathrm{N} \times$ 6.25) and fat (official CEC-method; Amtsblatt der Europäischen Gemeinschaften, 1971) contents, and total carbohydrate was calculated by difference.

Osmolality of urine was measured by freezing-point depression (Hermann Roebling Meßtechnik, Berlin, Germany), and $\mathrm{Na}$ and $\mathrm{K}$ concentrations were measured using ion-selective electrodes (model E2A Electrolyte Analyzer; Beckman Instruments, Stockholm, Sweden). Cortisol excretion in urine was measured by radioimmunoassay using an Amerlex Cortisol RIA kit (Amersham International plc, Amersham, Bucks., UK). For a detailed description of the method, see Madej et al. (1992). Catecholamines (adrenaline and nonadrenaline) were analysed with a commercial catecholamines $\left[{ }^{3} \mathrm{H}\right]$ radioenzymic assay system (Amersham International plc). The detection limit of the assay was below $100 \mathrm{pg} / \mathrm{ml}$, and all samples analysed had far higher concentrations. The interassay $\mathrm{CV}$ was $4 \%$ and the intraassay CV was about $10 \%$.

\section{Calculations of apparent digestibility and water balance}

The apparent digestibilities of crude protein, fat and total carbohydrate (by difference) in the experimental diet were

Table 1. Animals and design of experiments with low, medium or high ambient temperature $\left(T_{a} ; 5,15\right.$ or $\left.20-25^{\circ}\right)$ and water supply (ad libitum, N, or extra, E) to lactating female mink

\begin{tabular}{lcccccc}
\hline & & & \multicolumn{3}{c}{ Kit age $(\mathrm{d})$ at the start of period with $\mathrm{T}_{\mathrm{a}}$} \\
\cline { 4 - 6 } Female no. & Water supply & No. of kits & Low & Medium & High & End of expt \\
\hline 1 & $\mathrm{~N}$ & 6 & 12 & 15 & 18 & 20 \\
2 & $\mathrm{~N}$ & 6 & 12 & 15 & 18 & 20 \\
3 & $\mathrm{E}$ & 6 & 12 & 15 & 18 & 20 \\
4 & $\mathrm{E}$ & 6 & 12 & 15 & 18 & 20 \\
5 & $\mathrm{~N}$ & 3 & 10 & 13 & 16 & 18 \\
6 & $\mathrm{~N}$ & 7 & 10 & 13 & 16 & 18 \\
7 & $\mathrm{E}$ & 5 & 10 & 13 & 16 & 18 \\
8 & $\mathrm{E}$ & 6 & 10 & 13 & 16 & 18 \\
9 & $\mathrm{~N}$ & 5 & 8 & 11 & 14 & 15 \\
10 & $\mathrm{~N}$ & 5 & 7 & 10 & 13 & 16 \\
11 & $\mathrm{E}$ & 5 & 7 & 11 & 14 & 15 \\
12 & $\mathrm{E}$ & 7 & 7 & 10 & 13 & 15 \\
\hline
\end{tabular}


calculated for individual animals in each period as: (dietary intake of nutrient - faecal output of nutrient)/dietary intake of nutrient. The daily ME consumption $(\mathrm{kJ})$ was calculated as intake of digestible protein $(\mathrm{g}) \times 18.8+$ digestible fat $(\mathrm{g})$ $\times 39.8+$ digestible carbohydrate $(\mathrm{g}) \times 17.6)$ (Hansen et al . 1991).

Water balance was calculated as the difference between water intake in food and drinking-water and water output in urine and faeces. Results are presented both in g/animal per $\mathrm{d}$ and as $\mathrm{g} / \mathrm{kJ}$ ME intake.

\section{Calculation of water requirement for milk production}

The calculation of the water requirement for milk production was made by factorial approach based on the following data and assumptions. The daily weight gain of the individual kits was calculated for each period, and the metabolic live weights $\left(\mathrm{kg}^{0.75}\right)$ were calculated from average kit weights within each period. Data for body composition of the kits were taken from Tauson (1994a) for 5-d-old kits, and from $\mathrm{N}$ Glem-Hansen (unpublished results) for 24-d-old kits. The increases in protein and fat contents in the body were assumed to be linear over the period studied, resulting in increases in protein and fat of 0.1 and 0.25 percentage units respectively, per day increase in age. Daily protein and fat retentions were then calculated from daily weight gain and body composition data. Energy retained in protein was $23.86 \mathrm{~kJ} / \mathrm{g}$ and in fat $39.76 \mathrm{~kJ} / \mathrm{g}$ (Brouwer, 1965). The ME requirement for maintenance of the kits $\left(\mathrm{ME}_{\mathrm{m}}\right)$ was set at $527 \mathrm{~kJ} / \mathrm{kg}^{0.75}$ (Chwalibog et al. 1980), and ME for growth $\left(\mathrm{ME}_{\mathrm{g}}\right)$ was calculated by use of daily protein and fat accretion and the efficiencies of utilization for ME for protein retention $\left(k_{p}\right)$ and fat retention $\left(k_{f}\right)$ of $0.5 \mathrm{~kJ} / \mathrm{kJ}$ and $0.8 \mathrm{~kJ} / \mathrm{kJ}$ respectively, estimated on other singlestomached species (Klein \& Hoffman, 1989; Chwalibog,
1991). ME requirement for kits $\left(\mathrm{ME}_{\mathrm{kit}}\right)$ was calculated as the sum of $\mathrm{ME}_{\mathrm{m}}$ and $\mathrm{ME}_{\mathrm{g}}$. For milk consumption, data for $\mathrm{DM}\left(\mathrm{DM}_{\text {milk }}\right)$ and gross energy $\left(\mathrm{GE}_{\text {milk }}\right)$ contents from Olesen et al. (1992) were used, covering days 8-22 in lactation. Metabolizability of gross energy in milk was set at $0 \cdot 85$, and the daily milk requirement per kit (MILK) was calculated as MILK $=\mathrm{ME}_{\mathrm{kit}}\left(\mathrm{GE}_{\text {milk }} \times 0 \cdot 85\right)$. The daily water output in milk per female (WATER MILK $_{\text {) was calcu- }}$ lated as:

WATER $_{\text {MLK }}=$ no. of kits per litter $\times\left(\operatorname{MILK} \times\left(1-\mathrm{DM}_{\text {milk }}\right)\right)$.

\section{Statistical analyses}

ANOVA were carried out according to the general linear models procedure in Statistical Analysis Systems (1985). The following model (1) was used to evaluate the quantitative water intake and excretion data and the data on urinary osmolality, $\mathrm{Na}$ and $\mathrm{K}$ :

$$
Y_{i j k l}=\mu+a_{i}+b_{j}(i)+c_{k}+(a c)_{i k}+e_{i j k l}
$$

where $Y_{i j k l}$ is the $i j k l$ th observation, $\mu$ is the general mean, $a_{i}$ is the fixed effect of water supply, $b_{j}(i)$ is the effect of animal within water supply, $c_{k}$ is the fixed effect of period, $(a c)_{i k}$ is the interaction effect between water supply and period and $e_{i j k l}$ is the random error. Effect of water supply was tested by using random animal within water supply as an error term.

Data on ME consumption, water turnover in relation to ME consumption, $24 \mathrm{~h}$ excretion rates of $\mathrm{Na}, \mathrm{K}$, cortisol and catecholamines were evaluated with a model comprising the fixed effects of water supply and period and the interaction between these effects. Estimates of water requirement for milk production were tested regarding the fixed effect of period. Results are presented as least squares means

Table 2. Live weights of females and kits in experiments with low, medium or high ambient temperatures $\left(\mathrm{T}_{\mathrm{a}} ; 5,15\right.$ or $\left.20-25^{\circ}\right)$ and water supply (ad libitum, $\mathrm{N}$, and extra, $\left.\mathrm{E}\right)$ to lactating female mink

\begin{tabular}{|c|c|c|c|c|}
\hline & \multicolumn{2}{|c|}{ Water supply } & \multirow[b]{2}{*}{ RMSE } & \multirow[b]{2}{*}{$\begin{array}{c}\text { Effect of water } \\
\text { supply }(P=)\end{array}$} \\
\hline & $\mathrm{N}$ & $\mathrm{E}$ & & \\
\hline \multicolumn{5}{|c|}{ Experimental start/start of period with low $\mathrm{T}_{\mathrm{a}}$} \\
\hline Litter size & $5 \cdot 50$ & $5 \cdot 83$ & & \\
\hline Kit age (d) & 9 & 9 & & \\
\hline Female live weight $(\mathrm{g})$ & 1183 & 1135 & 149 & 0.59 \\
\hline Kit live weight $(\mathrm{g})$ & $41 \cdot 3$ & $43 \cdot 8$ & $16 \cdot 3$ & 0.53 \\
\hline \multicolumn{5}{|c|}{ Start of period with medium $\mathrm{T}_{\mathrm{a}}$} \\
\hline Female live weight (g) & 1197 & 1192 & 149 & 0.95 \\
\hline Kit live weight $(\mathrm{g})$ & $65 \cdot 3$ & $69 \cdot 3$ & 21.9 & $0 \cdot 44$ \\
\hline \multicolumn{5}{|l|}{ Start of period with high $\mathrm{T}_{\mathrm{a}}$} \\
\hline Female live weight (g) & 1179 & 1204 & 159 & $0 \cdot 79$ \\
\hline Kit live weight (g) & $86 \cdot 8$ & $90 \cdot 2$ & $25 \cdot 5$ & 0.58 \\
\hline \multicolumn{5}{|l|}{ End of experiment } \\
\hline Litter size & $5 \cdot 50$ & $5 \cdot 83$ & & \\
\hline Female live weight (g) & 1141 & 1146 & 154 & 0.96 \\
\hline Kit live weight $(\mathrm{g})$ & $100 \cdot 5$ & $102 \cdot 5$ & $27 \cdot 8$ & $0 \cdot 77$ \\
\hline
\end{tabular}

RMSE, root mean square error. 
achieved according to the described models. The significance level for differences between least squares means was determined by test with comparison-wise error rate $5 \%$, i.e. protected $t$ test after significant $F$ test (Fisher, 1935).

\section{Results}

\section{Animal performance}

Litter sizes averaged 5.5 and 5.8 kits for females given $\mathrm{N}$ and $\mathrm{E}$ water supply respectively, and all kits survived throughout the experimental period. Weight gain of the kits was not affected by water supply, and the recorded kit weights were normal. For $\mathrm{N}$ females live weights were stable until the start of the last period, during which they decreased. For E females, correspondingly, there was an increase in weight until the start of the last period, during which the weights decreased. There was not, however, any significant effect of water supply (Table 2).

\section{Quantitative water turnover}

Period had a significant influence on consumption of drinking water $(P=0.003)$, the consumption increasing with increasing $\mathrm{T}_{\mathrm{a}}$, and the intake of water with the food $(P=0.009)$, the intake decreasing with increasing $\mathrm{T}_{\mathrm{a}}$, but the total water intake was not affected by period. Period had a strong influence on faecal water, urinary water and total water output $(P<0 \cdot 001)$, the water output decreasing with increasing $\mathrm{T}_{\mathrm{a}}$. The combined effects, therefore, resulted in increased water balance with increasing $\mathrm{T}_{\mathrm{a}}(P=0 \cdot 008)$ (Fig. 1).

Water supply had no significant effect on water intake but for water output traits, treatment effects were more evident, with significantly less water voided in urine $(P=0.02)$ and in total $(P=0.04)$ for $\mathrm{N}$ animals. The water balance was independent of water supply $(P=0 \cdot 16)$ (Fig. 1).

\section{Metabolizable energy intake and water intake and excretion in relation to metabolizable energy intake}

ME intake decreased with increasing $\mathrm{T}_{\mathrm{a}}$. Period had a strong influence on water intake traits, with increases in drinking, dietary and total water intake per $\mathrm{kJ}$ ME as temperature increased. All output traits were affected by period, with the highest water output during the period with the low $\mathrm{T}_{\mathrm{a}}$. Water balance, on the other hand, increased when $T_{a}$ increased (Table 3).

ME intake of animals given $\mathrm{E}$ water supply was close to significantly $(P=0.06)$ higher than for $\mathrm{N}$ animals. Similar to the quantitative water output, water voided in urine and total water output were significantly affected by water supply, the highest outputs being achieved for animals given $\mathrm{E}$ water supply. Because $\mathrm{E}$ animals had lower water intake per $\mathrm{kJ}$ ME intake, water balance in relation to ME intake was highest for $\mathrm{N}$ animals (Table 3).

\section{Estimated water loss in milk and rectal temperature}

The calculated water loss in milk increased during the course of the experiment, reflecting the increasing ME requirement of the kits. Daily weight gain of the kits remained stable throughout the experiment, and hence $\mathrm{ME}_{\mathrm{g}}$ only increased slightly from the period with low $\mathrm{T}_{\mathrm{a}}$ to the two following periods (Table 4).

The rectal temperature of the females was above $40^{\circ}$ in all periods, and increased significantly during the two periods with medium and high $\mathrm{T}_{\mathrm{a}}$ (Table 4).

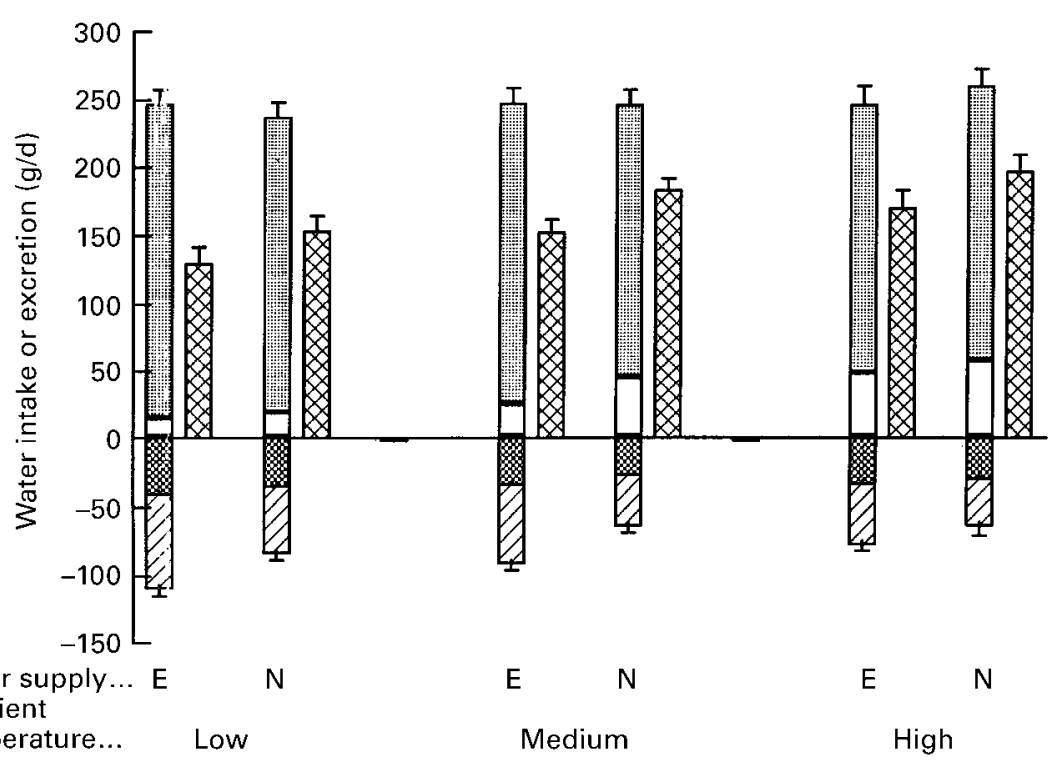

Fig. 1. Quantitative water turnover data for lactating female mink kept at low (about $5^{\circ}$ ), medium (about $15^{\circ}$ ) and high (about $20-25^{\circ}$ ) ambient

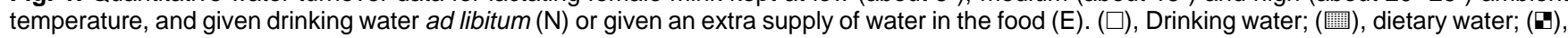
faecal water; (四), urinary water; (汹), balance. Values are means for twelve mink. Standard errors of the means, represented by vertical bars, are given for total water intake, total water excretion and water balance. Significant effects of $\mathrm{T}_{\mathrm{a}}$ were recorded for intake of drinking water $(P=0.003)$, dietary water $(P=0.009)$ and the faecal, urinary and total water excretion (all $P<0.001)$ as well as water balance $(P=0.008)$. Urinary $(P=0.02)$ and total $(P=0.04)$ water excretion values were lower in $\mathrm{N}$ than in $\mathrm{E}$ animals. 


\section{Urine osmolality and solute excretion}

The concentration of $\mathrm{Na}$ in urine was not affected either by water supply or by period. $\mathrm{K}$, on the other hand, was significantly higher in $\mathrm{N}$ animals $(P=0 \cdot 005)$, and also increased as $\mathrm{T}_{\mathrm{a}}$ increased $(P=0 \cdot 01)$. Also urine osmolality was significantly greater for $\mathrm{N}$ animals $(P=0.02)$ and increased with temperature $(P<0.001)$, the highest values of about $2600 \mathrm{mOsm} / \mathrm{kg}$ water being recorded for $\mathrm{N}$ animals at medium and high $\mathrm{T}_{\mathrm{a}}$ (Fig. 2).

The $24 \mathrm{~h}$ excretion of Na was significantly affected both by water supply and period, the highest excretion being recorded for $\mathrm{E}$ animals, but the rate of excretion decreased when $T_{a}$ increased. For $K$ excretion a similar tendency for higher excretion in E animals was found, and excretion decreased when temperature increased (Table 5).

In relation to $\mathrm{ME}$ consumption, $\mathrm{Na}$ excretion was not affected by period but was influenced by water supply, the excretion being highest for $\mathrm{E}$ animals. $\mathrm{K}$ excretion per $\mathrm{kJ}$ ME consumed was not significantly affected either by period or water supply (Table 3).
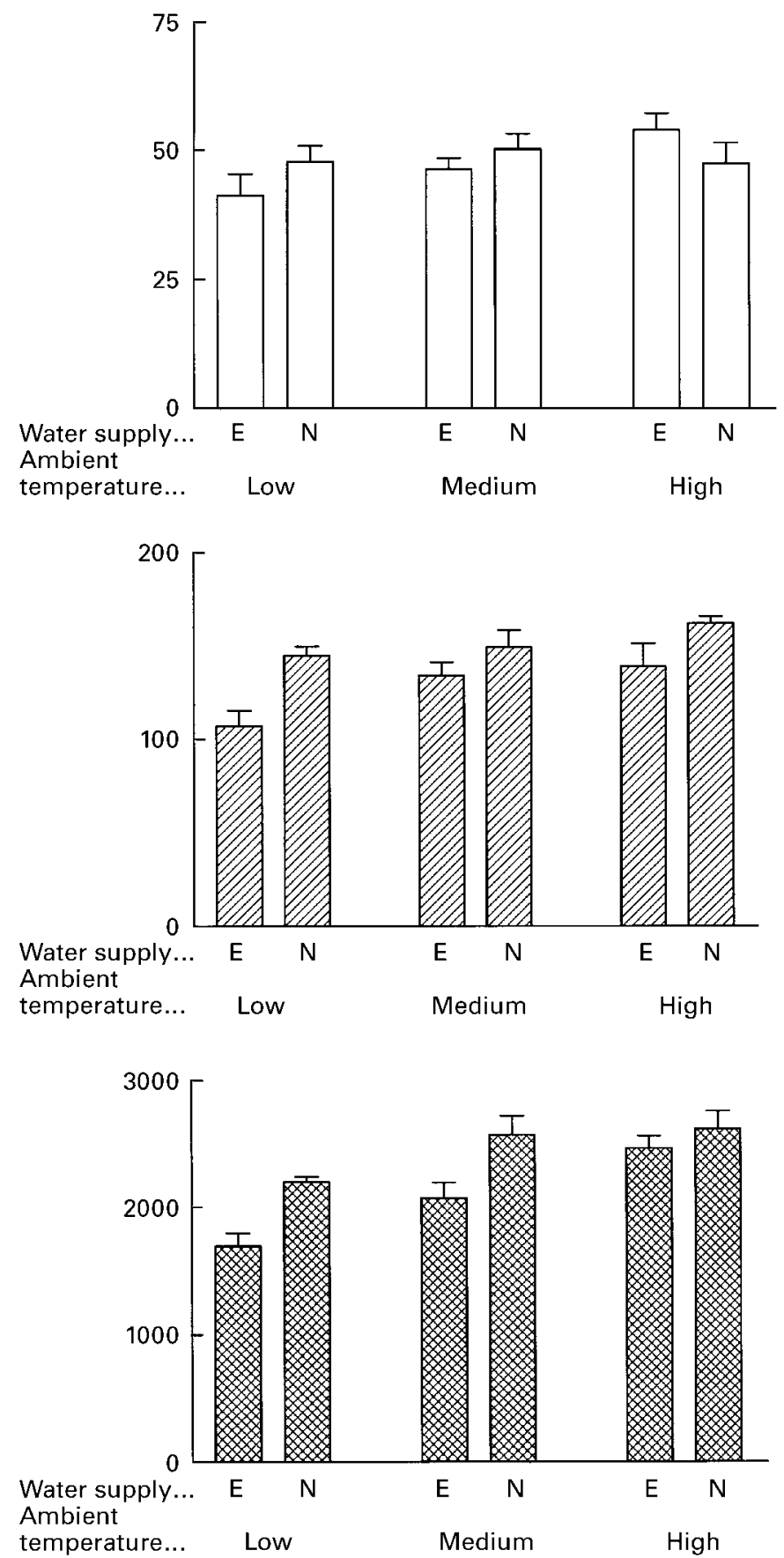

Fig. 2. Urinary excretion of sodium and potassium, and urinary osmolality for lactating female mink kept at low (about $\left.5^{\circ}\right)$, medium (about $\left.15^{\circ}\right)$ and high (about $20-25^{\circ}$ ) ambient temperature, and given drinking water ad libitum $(\mathrm{N})$ or given an extra supply of water in the food (E). Urinary potassium concentration was significantly affected by period $(P=0.01)$ and water supply $(P=0.005)$. Osmolality was significantly affected both by period $(P<0.001)$ and water supply $(P=0.02)$. 


\section{Urinary excretion of cortisol and catecholamines}

Cortisol excretion was independent of water supply and $\mathrm{T}_{\mathrm{a}}$. Catecholamines were not significantly affected by period, but at low and medium temperatures the highest excretion was recorded for $\mathrm{E}$ animals (Table 5).

\section{Discussion}

\section{Ambient temperature}

The present investigation was performed in a period which corresponded to increasing milk production, but most probably the females had not yet reached peak lactation. Despite this, the daily water intake and excretion values were greater than those found in males (A-H Tauson, unpublished results) of approximately double the body weight.

Most water intake and excretion traits were strongly affected by period, but since it was not technically possible to divide the experimental facilities into separate compartments that could be individually climatized, and the mink whelping season is very concentrated in time, the animals had to be exposed to the different temperature treatments consecutively, and hence effects of period cannot be ascribed unambiguously to the increase in $\mathrm{T}_{\mathrm{a}}$, but may also, to some extent, be explained by increasing metabolic demands on the females to support the energy requirement of the growing kits. On the other hand, previous findings (A$\mathrm{H}$ Tauson, unpublished results) have given clear evidence for a strong influence of temperature on the total water intake and excretion.

The present results demonstrate clearly that ME intake decreased from the first to the last period, a change which was probably caused by the increase in $\mathrm{T}_{\mathrm{a}}$, because lactating mink normally increase their ME intake considerably during the first 3 weeks of lactation (Tauson, 1997). For lactating dams a low ME intake is a serious problem because it will lead to energy deficit and concomitant mobilization of body reserves. Since lactating mink are usually in negative energy balance after the third week of lactation (Tauson, 1997; Tauson et al. 1998) even under normal temperature conditions, and weight losses during a 6-week lactation period are in the order of 15-25\% (Tauson, 1988, 1994b; Hansen \& Berg, 1998), a decrease in ME intake caused by a high $\mathrm{T}_{\mathrm{a}}$ may result in excessive weight loss and eventually in

Table 3. Effect of periods with low, medium or high ambient temperature $\left(5,15\right.$ and $\left.20-25^{\circ}\right)$ and different water supply ( $\mathrm{N}$, ad libitum drinking water supply, or E, extra water supplementation in the food) on metabolizable energy (ME) intake and water intake and excretion, and urinary excretion of $\mathrm{Na}$ and $\mathrm{K}$ per $\mathrm{kJ} \mathrm{ME}$ consumed in lactating female mink

\begin{tabular}{|c|c|c|c|c|c|c|c|c|}
\hline & \multicolumn{3}{|c|}{ Ambient temperature } & \multicolumn{2}{|c|}{ Water supply } & \multirow[b]{2}{*}{ RMSE } & \multicolumn{2}{|c|}{ Effect of $(P=)$} \\
\hline & Low & Medium & High & $E$ & $\mathrm{~N}$ & & Period & Water supply \\
\hline ME intake $(\mathrm{kJ} / \mathrm{d})$ & $1543^{a}$ & $1417^{b}$ & $1212^{b}$ & 1467 & 1315 & 230 & 0.005 & 0.06 \\
\hline $\begin{array}{l}\mathrm{Na}(\mu \mathrm{mol} / \mathrm{kJ} \mathrm{ME}) \\
\mathrm{K}(\mu \mathrm{mol} / \mathrm{kJ} \mathrm{ME})\end{array}$ & $\begin{array}{l}1 \cdot 9 \\
5 \cdot 1\end{array}$ & $\begin{array}{l}1 \cdot 7 \\
4 \cdot 9\end{array}$ & $\begin{array}{l}1 \cdot 7 \\
4 \cdot 7\end{array}$ & $\begin{array}{l}2 \cdot 0 \\
5 \cdot 1\end{array}$ & $\begin{array}{l}1 \cdot 5 \\
4 \cdot 7\end{array}$ & $\begin{array}{l}0 \cdot 6 \\
1 \cdot 3\end{array}$ & $\begin{array}{l}0.31 \\
0.63\end{array}$ & $\begin{array}{l}0.002 \\
0 \cdot 16\end{array}$ \\
\hline
\end{tabular}

RMSE, root mean square error.

a,b,c Mean values within a row not sharing a common superscript letter were significantly different, $P<0.05$.

Table 4. Metabolic live weight of mink females and kits, female rectal temperature, water requirement for milk production and energy requirement of kits at low, medium or high ambient temperature $\left(5,15\right.$ or $\left.20-25^{\circ}\right)$

\begin{tabular}{|c|c|c|c|c|c|}
\hline & \multicolumn{3}{|c|}{ Ambient temperature } & \multirow[b]{2}{*}{ RMSE } & \multirow[b]{2}{*}{$\begin{array}{c}\text { Effect of } \\
\text { period }(P=)\end{array}$} \\
\hline & Low & Medium & High & & \\
\hline \multicolumn{6}{|l|}{ Females } \\
\hline Metabolic weight* $\left(\mathrm{kg}^{0.75}\right)$ & $1 \cdot 11$ & $1 \cdot 13$ & $1 \cdot 11$ & $0 \cdot 10$ & 0.50 \\
\hline Rectal temperature $\left(^{\circ}\right)$ & $40 \cdot 6^{a}$ & $41 \cdot 4^{\mathrm{ab}}$ & $41 \cdot 7^{b}$ & 0.65 & $<0.001$ \\
\hline $\begin{array}{l}\text { Water requirement for } \\
\text { milk production }(\mathrm{g} / \mathrm{d})\end{array}$ & $118^{\mathrm{a}}$ & $129^{\mathrm{ab}}$ & $134^{b}$ & 41 & 0.05 \\
\hline \multicolumn{6}{|l|}{ Kits } \\
\hline $\begin{array}{l}\text { Metabolic weight* }\left(\mathrm{kg}^{0.75}\right) \\
\mathrm{ME}_{\mathrm{m}}(\mathrm{kJ} / \text { kit per } \mathrm{d}) \\
\mathrm{ME}(\mathrm{kJ} / \text { kit per } \mathrm{d})\end{array}$ & $\begin{array}{l}0 \cdot 112 \\
59^{\mathrm{a}} \\
115^{\mathrm{a}}\end{array}$ & $\begin{array}{l}0 \cdot 146 \\
77^{\mathrm{b}} \\
144^{\mathrm{b}}\end{array}$ & $\begin{array}{l}0 \cdot 170 \\
89^{\mathrm{c}} \\
151^{\mathrm{b}}\end{array}$ & $\begin{array}{l}0 \cdot 03 \\
17 \\
43\end{array}$ & $\begin{array}{l}<0.001 \\
<0.001 \\
<0.001\end{array}$ \\
\hline
\end{tabular}

RMSE, root mean square error; $M E$, metabolizable energy; $\mathrm{ME}_{\mathrm{m}}$, ME requirement for maintenance.

a,b,c Mean values within a row not sharing a common superscript letter were significantly different, $P<0.05$

* Average of the live weight at the start and end of each period. 
respectively, but in fair agreement with those of Sørensen (1995) who found evaporative water loss in lactating mink in the order of $60 \mathrm{~g} /$ female per $\mathrm{d}$.

\section{Renal solute excretion}

The urinary concentration of $\mathrm{Na}$ was not affected by water supply, and $24 \mathrm{~h}$ excretion was higher for $\mathrm{E}$ than for $\mathrm{N}$ animals. This indicates that regulation of $\mathrm{Na}$ excretion is less accurate in lactating than in dry animals, and therefore the lactating female may be expected to be more susceptible to changes in the Na concentration of the food. The pattern for excretion of $\mathrm{K}$ suggested that physiological stage and environmental effects have less influence on the excretion of this electrolyte.

\section{Urinary cortisol and catecholamines as stress indicators}

Cortisol and catecholamine excretion rates in urine over $24 \mathrm{~h}$ were used as possible indicators of stress, since blood sampling can be stressful to the animals, and levels found in plasma, therefore, may be of limited value. From the results achieved, it appears that neither water supply nor $T_{a}$ influenced cortisol excretion. It may, however, be doubted whether cortisol is specific enough to be a good measure of stress. Hence, Olsson et al. (1995) found that positive stress could result in plasma concentrations similar to those given by negative stress. Catecholamines were not affected by period but were affected to some extent by water supply; however, the results only represent every second animal, and only urine collected during the last day of each period, which of course limits their reliability. Therefore, the present results cannot be taken as any clear evidence regarding the degree of stress that the high $\mathrm{T}_{\mathrm{a}}$ had inflicted on the animals.

\section{Conclusions}

A prolonged period of high $\mathrm{T}_{\mathrm{a}}$ may be hazardous for lactating mink because of a decrease in ME intake which, if persisting over an extended time period, may lead to excessive weight loss and possibly result in nursing sickness. Therefore, if a heatwave occurs during the lactation period, all possible precautions to cool the environment and to secure the supply of high quality food and drinking water must be taken in order to sustain dam and kit welfare and performance.

\section{Acknowledgements}

Ms Christina Norberg is heartily thanked for excellent technical assistance, comprising skilful handling of the animals, accurate collection routines and precise analytical work. The author is grateful to Dr Andrzej Madej, Department of Physiology, for taking on the laborious task of the catecholamine analyses. Ms Anna-Greta Haglund is thanked for performing the $\mathrm{Na}, \mathrm{K}$ and osmolality analyses, and Professor Sigvard Thomke for reading and making constructive comments on the manuscript. Financial support was provided by Stiftelsen Pälsdjurscenter i Sölvesborg.

\section{References}

Amtsblatt der Europäischen Gemeinschaften L 279 (1971) 17 Official Journal of the European Communities L279 (1971), p. 995 .

Brouwer E (1965) Report of sub-committee on constants and factors. Proceedings of the 3rd Symposium on Energy Metabolism. European Association for Animal Production Publication no. 11, pp. 441-443 [KL Blaxter, editor]. London: Academic Press.

Chwalibog A (1991) Energetics of animal production. Research in Copenhagen, review and suggestions. Acta Agriculturae Scandinavica 41, 147-160.

Chwalibog A, Glem-Hansen N \& Thorbek G (1980) Energy metabolism in adult mink in relation to protein-energy levels and environmental temperature. Proceedings of the 8th Symposium on Energy Metabolism. European Association for Animal Production Publication no. 26, pp. 283-286 [LE Mount, editor]. London: Butterworths.

Clausen TN, Olesen CR, Hansen O \& Wamberg S (1992) Nursing sickness in lactating mink (Mustela vison) I. Epidemiological and pathological observations. Canadian Journal of Veterinary Research 56, 89-94.

Farrell DJ \& Wood AJ (1968) The nutrition of the female mink. III. The water requirement for maintenance. Canadian Journal of Zoology 46, 53-56.

Fisher RA (1935) The Design of Experiments. Edinburgh: Oliver and Boyd.

Hansen BK (1997) The lactating mink (Mustela vison) - Genetic and metabolic aspects. PhD Thesis, Department of Animal Science and Animal Health, The Royal Veterinary and Agricultural University, Copenhagen.

Hansen BK \& Berg P (1998) Mink dam weight changes during the lactation period I. Genetic and environmental effects. Acta Agriculturce Scandinavica, Section A, Animal Science 48, 49-57.

Hansen M (1974) Ny og bedre metode til påvisning af plasmacytose (New and improved method to diagnose Aleuthian disease). Dansk Pelsdyravl 37, 209-211.

Hansen NE, Finne L, Skrede A \& Tauson A-H (1991) Energiforsyningen hos mink og rev (The energy supply of mink and foxes). NJF utredning/rapport no. 63, DSR Forlag, Landbohøjskolen, Copenhagen.

Juokslahti T (editor) (1987) Vitamins in the Nutrition of Fur Bearing Animals, pp. 1-70. Basle: Roche A/S.

Klein M \& Hoffman L (1989) Bioenergetics of protein retention. In Protein Metabolism in Farm Animals, Evaluation, Digestion, Absorption, and Metabolism, pp. 404-440 [HD Bock, BO Eggum, AG Low, O Simon and T Zebrowska, editors]. Berlin: Oxford Science Publications and Deutscher Landwirtschaftsverlag.

Madej A, Forsberg M \& Edqvist L-E (1992) Urinary excretion of cortisol and oestrone sulfate in pregnant mink fed PCB and fractions of PCB. Ambio 21, 582-585.

Maksimov AP (1973) A rational regimen of watering for mink. Nutrition Abstracts and Reviews 44, 1974 Abstr.

Neil M (1988) Effects of dietary energetic composition and water content on water turnover in mink. Swedish Journal of Agricultural Research 18, 135-140.

Neil M (1992) Supplementary dietary water to mink in lactation and early kit growth. Swedish Journal of Agricultural Research 22, 125-129.

Nes N, Einarsson EJ \& Lohi I (1987) Beautiful Fur Animals - and their Colour Genetics. Hillerød, Denmark: Scientifur.

Olesen CR, Clausen TN \& Wamberg S (1992) Compositional changes in mink (Mustela vison) milk during lactation. Norwegian Journal of Agricultural Sciences Suppl. 9, 308-314.

Olsson K \& Dahlborn K (1989) Fluid balance during heat stress in lactating goats. Quarterly Journal of Experimental Physiology 74, 645-659. 
Olsson K, Josäter-Hermelin M, Hossaini-Hilali J, Hydbring E \& Dahlborn K (1995) Heat stress causes excessive drinking in fed and food deprived pregnant goats. Comparative Biochemistry and Physiology 110A, 309-317.

Sørensen HJ (1995) Water turnover in pregnant and lactating female mink. MSc Thesis, Department of Animal Science and Animal Health, The Royal Veterinary and Agricultural University, Copenhagen.

Statistical Analysis Systems (1985) SAS User's Guide: Statistics. Cary, NC: SAS Institute Inc.

Tauson A-H (1988) Varied energy concentration in mink diets. II. Effects on kit growth performance, female weight changes and water turnover in the lactation period. Acta Agricultura Scandinavica 38, 231-242.

Tauson A-H (1994a) Postnatal development in mink kits. Acta Agriculturce Scandinavica, Section A, Animal Science 44, 177-184.

Tauson A-H (1994b) High dietary level of polyunsaturated fatty acids and varied vitamin E supplementation in the reproduction period of mink. Journal of Animal Physiology and Animal Nutrition 72, 1-13.

Tauson A-H (1997) Prolactin profiles in pregnant, lactating and non-mated female mink (Mustela vison). Journal of Reproduction and Fertility, Suppl. 51, 195-201.
Tauson A-H, Sørensen HJ, Wamberg S \& Chwalibog A (1998) Energy metabolism, nutrient oxidation and water turnover in the lactating mink (Mustela vison). Journal of Nutrition 128 (In the Press).

Wamberg S (1994) Rates of heat and water loss in female mink (Mustela vison) measured by direct calorimetry. Comparative Biochemistry and Physiology 107A, 451-458.

Wamberg S, Clausen TN, Olesen CR \& Hansen O (1992) Nursing sickness in lactating mink (Mustela vison) II. Pathophysiology and changes in body fluid composition. Canadian Journal of Veterinary Research 56, 95-101.

Wamberg S \& Tauson A-H (1998) Daily milk intake, body growth and body water turnover in suckling mink (Mustela vison) kits. Comparative Biochemistry and Physiology A 119, 931-939.

Wustenberg W \& Wustenberg M (1988) Reducing heat stress in mink production units: basic principles of environmental control. In Biology, Pathology and Genetics of Fur Bearing Animals. Proceedings of the 4th International Scientific Congress in Fur Animal Production, pp. 130-135 [BD Murphy and DB Hunter, editors]. Toronto, ON: International Fur Animal Science Association. 